\title{
Phytotoxic and genotoxic effect of Aluminum to date palm (Phoenix dactylifera L.) in vitro cultures
}

\author{
Khairullah M. Awad', Ansam M. Salih', Yahya Khalaf ${ }^{1}$, Aqeel A. Suhim ${ }^{1}$ and Mohammed Hamza Abass ${ }^{2 *}$ (D)
}

\begin{abstract}
Background: $\mathrm{Al}$ is a common metallic element found in earth's crust and is a toxic pollutant present at high concentrations in acidic soil, thus affecting plant growth. Despite being well studied as a toxic element, the effects of Al on date palm have not been investigated. This study aimed to assess the toxic effects of different Al concentrations on the development and growth of date palm callus and evaluate the biochemical and molecular response of date palm cells under Al stress.

Results: Our study revealed the phytotoxicity of Al concentrations (50, 100, 150 and $200 \mathrm{mg} . \mathrm{l}^{-1}$ ) on date palm callus. The fresh and dry weight and the number of produced embryos were significantly decreased in response to Al concentration. At $150 \mathrm{mg} . \mathrm{I}^{-1}$, the embryo number decreased to 1.66 compared with the 19.33 in the control treatment. At high Al concentration (200 mg. ${ }^{-1}$ ), the callus failed to produce any embryo. Biochemical analysis revealed that $\mathrm{Al}$ exposure had negative effect on callus. Total soluble carbohydrates, total soluble protein and free amino acids were decreased in plants receiving $200 \mathrm{mg}^{-1} \mathrm{l}^{-1} \mathrm{Al}$ treatment compared with those in the untreated ones. A similar decline was observed in total soluble protein and free amino acid in response to $\mathrm{Al}$ treatment. Significant accumulations of malondialdehyde, $\mathrm{H}_{2} \mathrm{O}_{2}$ and peroxidase activity accompanied the increase in $\mathrm{Al}$ concentration in cultured tissues, revealing the generation of toxic reactive oxygen species in affected cultures. The genotoxic effect of Al at high concentrations (150 and $200 \mathrm{mg}^{-1} \mathrm{l}^{-1}$ ) was revealed by protein patterns.

Conclusion: Our findings revealed for the first time the phytotoxicity of Al to date palm callus. At $200 \mathrm{mg} . \mathrm{I}^{-1}, \mathrm{Al}$ prevented the embryo production of date palm callus. At 50, 100, 150 and $200 \mathrm{mg} . \mathrm{I}^{-1}$, Al negatively affected the biochemical characteristics of date palm callus. At 150 and $200 \mathrm{mg}^{-\mathrm{I}^{-1}}$, Al induced changes in protein expression. These data showed that the tissue culture technique can be used as a valuable approach in heavy metal toxicity studies.
\end{abstract}

Keywords: Aluminum, biochemical analysis, date palm, pollution, protein patterns

\section{Background}

Soil acidification is a result of industrial and agricultural activities that lead to the accumulation of toxic ions, including $\mathrm{Al}, \mathrm{Zn}, \mathrm{Cu}, \mathrm{Pb}$ and $\mathrm{Cd}$ [7]. $\mathrm{Al}$ is the third most abundant element in the earth's crust but is not considered as an essential nutrient; however, an increased plant growth is observed in soils with low $\mathrm{Al}$ concentrations [37]. In soil $\mathrm{pH}$ of 5.5 or lower, $\mathrm{Al}$ is a toxic factor that limits crop growth and productivity [23, 27]. Al toxicity

\footnotetext{
* Correspondence: dr.mha24@yahoo.co.uk

${ }^{2}$ Plant Protection Department, College of Agriculture, University of Basra, Basra 61001, Iraq

Full list of author information is available at the end of the article
}

has several consequences of, including root growth inhibition, oxidative stress as a result of reactive oxygen species (ROS) generation, alteration of cell wall and plasma membrane characteristics, nutrient unbalances, cytoplasmic $\mathrm{Ca}^{2}+$ efflux and induction of callose $(1,3-\beta$ -D-glucan) formation [26, 37, 38, 41]. The use of in vitro tissue culture technique is suitable to study the physiological effects of $\mathrm{Al}$ and allows the application of cells with uniform growth and the investigation of physiological and biochemical Al toxicity at the cellular level $[20,39,45]$. The negative effects of Al toxicity in cultured cells for some plant species, such as tomato [28], tobacco [50], wheat [11], Citrus species [46] and Lobelia 
chinensis [18], have been investigated. Al toxicity inhibits cell division and elongation, reduces cell growth and decreases callus fresh and dry mass. $\mathrm{Al}$ also has deleterious effects on the genomic stability of cells cultured in vitro [37]; hence, DNA is the first target of Al toxicity in plant systems because of its presence in the cytoplasm and nucleus of coffee cell protoplast. Furthermore, DNA degradation and cell growth inhibition have been observed, [15] indicating that $\mathrm{Al}$ at high concentrations negatively affects double helix rigidity and thus reduces DNA replication.

$\mathrm{Al}$ induces protein expression alteration and changes protein profile by inducing the up- and down-regulation of proteins with different expression patterns as revealed by the appearance and disappearance of protein bands in SDS PAGE $[12,44,46]$. Date palm Phoenix dactylifera L. belongs to the Arecaceae family and is cultivated mainly for their nutritive fruits [3]. This tree is propagated through seeds, offshoots and tissue culture technology [52]. With tissue culture approach, date palm can propagate by two main methods, namely, somatic embryogenesis and auxiliary bud formation [1,5]. In vitro date palm tissue culture at callus induction stage is used to induce and increase total steroids by adding some heavy metals ( $\mathrm{Cd}$ and $\mathrm{Al}$ ) to basal nutrient medium, [53] thereby substantially increasing the total steroid content of date palm callus compared with that of the control treatment.

$\mathrm{Al}$ toxicity on date palms have been not been investigated either on whole plants or at the cellular level. Thus, this study was designed to assess the effects of different $\mathrm{Al}$ concentrations on the development and growth of date palm callus and evaluate the biochemical and molecular responses of date palm cells under $\mathrm{Al}$ stress.

\section{Methods}

\section{Prepare culture medium}

Culture medium was prepared with concentration 4.33 gm. $\mathrm{L}^{-1}$ from MS salts [31] provided from Zist Arman Sabz company, supplemented with additions presented in Table 1 , then the medium $\mathrm{pH}$ was adjusted to 5.8 with $\mathrm{NaOH}(1 \mathrm{~N})$ and autoclaved, after that Aluminum (Al) was at different concentrations, the experimental treatments as follow:

1. $\mathrm{Al}_{0}$ as control treatment

2. $\mathrm{Al}_{50}$ which $\mathrm{Al}$ added at $50 \mathrm{mg} . \mathrm{l}^{-1}$

3. $\mathrm{Al}_{100}$ which $\mathrm{Al}$ added at $100 \mathrm{mg} \cdot \mathrm{l}^{-1}$.

4. $\mathrm{Al}_{150}$ which $\mathrm{Al}$ added at $150 \mathrm{mg} \cdot \mathrm{l}^{-1}$.

5. $\mathrm{Al}_{200}$ which $\mathrm{Al}$ added at $200 \mathrm{mg} \cdot \mathrm{l}^{-1}$.

$\mathrm{Al}$ was supplemented as $\mathrm{AlCl}_{3}$ with micro filters to avoid microbial pollution. The culture medium was
Table 1 Additions supplemented to culture medium of date palm callus

\begin{tabular}{ll}
\hline Addition & Concentration g. I $^{-1}$ \\
\hline Sucrose & 30 \\
$\mathrm{Na}_{2} \mathrm{H}_{2} \mathrm{PO}_{4}$ & 170 \\
Myo-inositol & 125 \\
Glutamine & 200 \\
Thiamine & 5 \\
Nicotinic acid & 1 \\
Pyridoxine-HCl & 1 \\
2,4-D & 50 \\
2iP & 3 \\
Agar & 7 \\
Activated charcoal & 1.5 \\
\hline
\end{tabular}

poured in test tubes and closed tightly with cotton and then wrapped with aluminum foil.

\section{Plant materials}

Embryogenesis callus of date palm derived from date palm shoot tips of Hillawi cultivar, provided from tissue culture laboratory in Date Palm Research Centre- Basrah University, cultured into medium already prepared with $50 \mathrm{mg}$ as initial weight, callus inoculated into medium in test tubes and incubated with conditions, $25 \pm 2^{\circ} \mathrm{C}$ in a dark culture room for 12 weeks, callus subjected to reculture every four weeks.

After incubation period, Al toxicity was evaluated by following characteristics:

\section{Fresh and dry weight and embryo numbers of date palm callus}

Fresh and dry weight was measured after incubation period; also counted the number of embryos was generated on date palm callus.

\section{Total Soluble carbohydrates}

Date palm callus content of total soluble carbohydrates was estimated depended on Anthrone (97\%, Sigma Aldrich, USA) reaction according to [47], the absorbance was measured at $620 \mathrm{~nm}$ and glucose was used to prepared standard curve.

\section{Total soluble protein}

[8] Protocol was followed to measure the total soluble protein; Albumin was used as standard curve and absorbance measured at $595 \mathrm{~nm}$.

\section{Free amino acids}

Procedure of [25] was followed to estimate the free amino acids and optical density was measured at $570 \mathrm{~nm}$. 


\section{Malondialdehyde (MDA)}

MDA was quantified as a marker of membrane lipid peroxidation, MDA was extracted $5 \%(\mathrm{w} / \mathrm{v})$ with trichlotoacetic acid (TCA) (99\%, Himedia, India), the absorbance at 532 and $600 \mathrm{~nm}$ was used, a calculation of MDA content was done depending on extinction coefficient of 155 [17].

\section{Hydrogen Peroxide $\left(\mathrm{H}_{2} \mathrm{O}_{2}\right)$}

$\mathrm{H}_{2} \mathrm{O}_{2}$ content was measured calorimetrically at $390 \mathrm{~nm}$ according to [40], $\mathrm{H}_{2} \mathrm{O}_{2}$ (38\%, Evonik, Germany) was used to create a standard curve.

\section{Peroxidase enzyme activity}

Procedure of [22] was used to estimate peroxidase activity $(\mathrm{U} / \mathrm{min} / \mathrm{g})$ depending on the variation of absorption at $470 \mathrm{~nm}$ as a result of tetraguaiacol production.

\section{SDS PAGE electrophoresis}

Isolate protein were applied to sodium dodecyl sulphate polyacrylamide gel electrophoresis (SDS PAGE), under non-denaturing procedure as described in [24]. The procedure of [29] to stain and destain the gel with commassie brilliant blue was followed. Electrophoretic stacking was performed using $4 \%$ polyacrylamide gels and $10 \%$ for electrophoretic separation at $4{ }^{\circ} \mathrm{C}$ for $7 \mathrm{~h}$. Promega $(10-225 \mathrm{KDa})$ was used as protein molecular weight marker, fragments photographed under UV light, the detection of fragments molecular weights was performed using the PhotoCapt MW software 10.0 (Vilber Loumart).

The binary matrix was created according to the fragments present (1) or absent (0); and equation of [32] was followed to measure the genetic similarity index (GSI) as:

$$
G S I=\frac{2 A}{B+C}
$$

where (A) number of similar fragments in both treatments, (B) and (C) total number of bands in the first and second treatments.

\section{Genetic distance $=1-$ GSI}

Where (GSI) genetic similarity index as explained in the equation above.

The similarity index was used to produce the dendrogram using the unweighted pair group mean average (UPGMA) method [42].

\section{Statistical analysis}

The complete randomized design was used. The obtained data was analyzed with one way analysis of

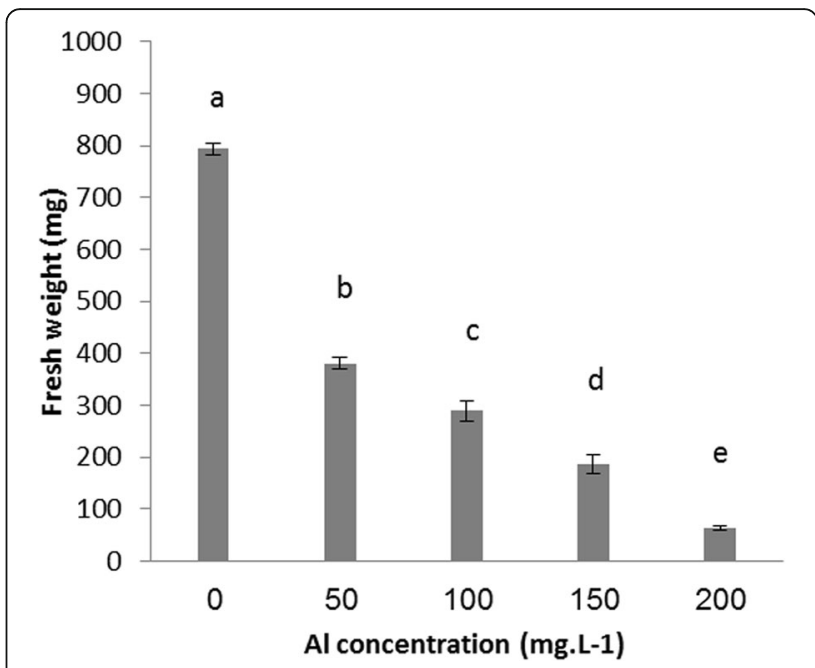

Fig. 1 Al toxicity on fresh weight of date palm callus

variance (ANOVA), the mean treatments were compared with Least Significant Difference (LSD) test at the probability level of 0.01 , statistical analysis was done by using the SPSS-22 statistical software (SPSS In., Chicago, IL., USA) version 22.

\section{Results}

The effect of Al treatments on fresh, dry weight and embryo numbers of date palm callus

Results presented in Figs. 1 and 2 revealed the toxic effect of $\mathrm{Al}$ at a range of concentrations on both fresh and dry weight of date palm callus, Fig. 1 showed that the fresh weight of date palm callus was reached $794.33 \mathrm{mg}$ in control treatment after 12 weeks, while the fresh weight was decreased significantly to 380.33 ,

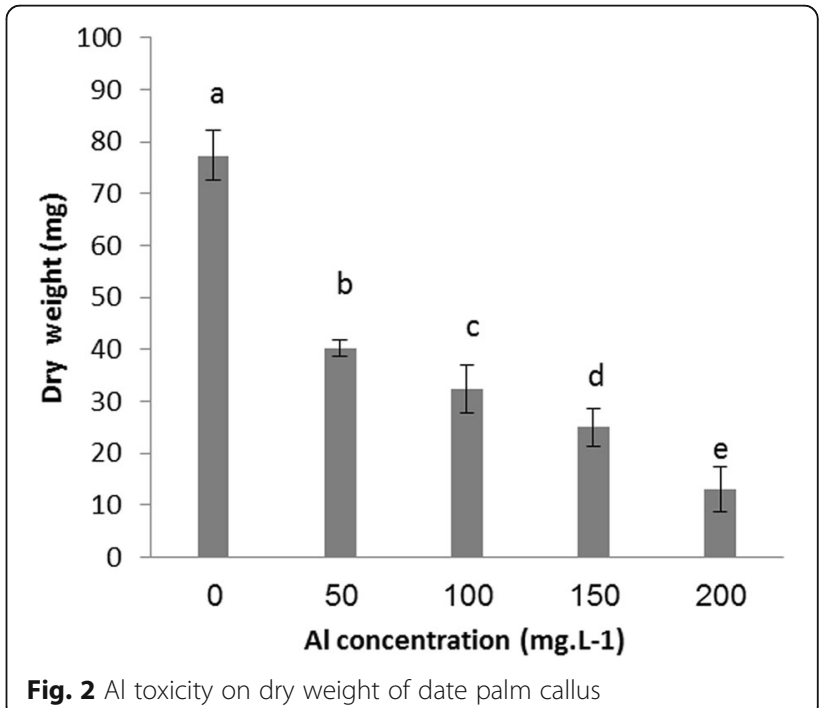




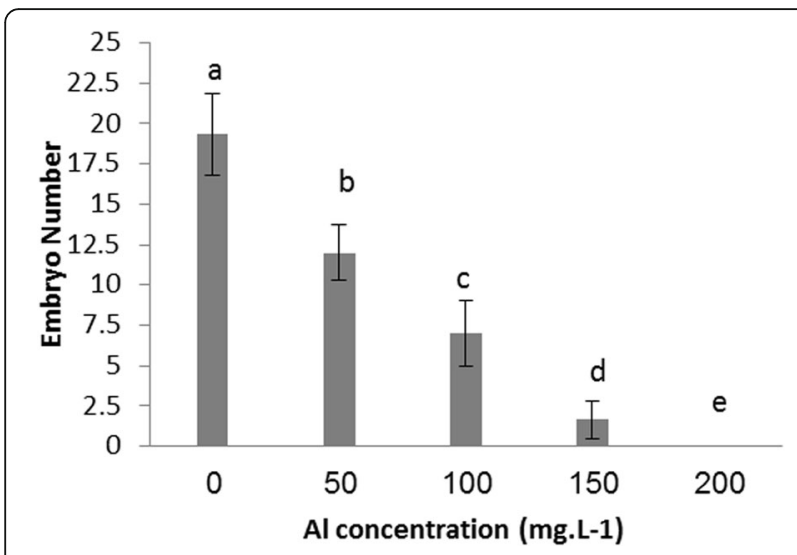

Fig. 3 Al toxicity on embryo number of date palm callus

288.66, 180.66 and $63.00 \mathrm{mg}$ when callus propagated in medium contain $\mathrm{Al}$ at 50,100,150 and $200 \mathrm{mg} . \mathrm{l}^{-1}$ respectively. Dry weight of callus was affected when exposed to $\mathrm{Al}$ at all investigated concentrations; the highest value of dry weight was recorded in control treatment which was $77.33 \mathrm{mg}$, while the lowest was recorded in callus exposed to $\mathrm{Al}$ at $200 \mathrm{mg} . \mathrm{l}^{-1}$ which was $13.00 \mathrm{mg}$. Results in Fig. 3 showed the dry weight was $40.33,32.33$ and $25.00 \mathrm{mg}$ in $\mathrm{Al}$ at 50,100 and 150 mg. $\mathrm{l}^{-1}$ treatments, respectively.

Regarding the embryos number, the results illustrated in Fig. 3 showed, the callus treated with $\mathrm{Al}$ at $200 \mathrm{mg} \cdot \mathrm{l}^{-1}$ did not produced any embryo after 12 weeks, while the embryos numbers were 12,7 and 1.66 when callus of date palm cultured on a medium supplemented with $\mathrm{Al}$ at 50,100 and $150 \mathrm{mg} \cdot \mathrm{l}^{-1}$ respectively, it is noted from results the control treatment produced 19.33 embryos.

\section{Biochemical responses of date palm callus to $\mathrm{Al}$ treatments}

The biochemical characteristics of date palm callus under $\mathrm{Al}$ treatments were evaluated after 12 weeks, exposure to $\mathrm{Al}$ resulted in a significant reduction in carbohydrates, proteins and free amino acids content, in contrast a significant increase in MDA, $\mathrm{H} 2 \mathrm{O} 2$ and peroxidase enzyme activity. The results in Table 2 showed a significant effect of $\mathrm{Al}$ treatments on total soluble carbohydrates content in date palm callus in comparison to unexposed callus; the highest level of carbohydrates was recorded in control treatment which was $5.87 \mathrm{mg} . \mathrm{g}^{-1}$ while $\mathrm{Al}$ treatment at $200 \mathrm{mg} \cdot \mathrm{g}^{-1}$ produced the lowest carbohydrate level $0.54 \mathrm{mg} . \mathrm{g}^{-1}$. Similar reduction was observed with protein content, $\mathrm{Al}$ at $200 \mathrm{mg} \cdot \mathrm{l}^{-1}$ declined total soluble protein content from $3.39 \mathrm{mg} \cdot \mathrm{g}^{-1}$ in control treatment to $0.27 \mathrm{mg} \cdot \mathrm{g}^{-1}$, while the protein content were $1.82,1.23$ and $0.78 \mathrm{mg} . \mathrm{g}^{-1}$ when callus exposed to $\mathrm{Al}$ at 50, 100 and $150 \mathrm{mg} \cdot \mathrm{l}^{-1}$ respectively. Free amino acids content decreased significantly with $\mathrm{Al}$ concentration increase and it was evident in callus exposed to $\mathrm{Al}$ at 200 mg. $\mathrm{l}^{-1}$, the free amino acids content in control treatment was $1.66 \mathrm{mg} \cdot \mathrm{g}^{-1}$ reduced to $0.16 \mathrm{mg} \cdot \mathrm{g}^{-1}$ in $\mathrm{Al}$ at 200 mg. $l^{-1}$ treatment.

Opposite trend of results was seen with Malondialdehyde (MDA), the obtained results revealed MDA content was increased in treated callus with $\mathrm{Al}$, thus, was evident by the increase of MDA content from $0.46 \mathrm{nmole}^{-1}$ in control to $0.56,0.60,0.71$ and 0.79 nmole. $^{-1}$ for $\mathrm{Al}$

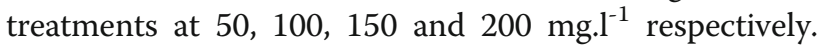
Results showed that, $\mathrm{Al}$ treatments $(50,100$ and 150 mg. $1^{-1}$ ) had no effect on $\mathrm{H}_{2} \mathrm{O}_{2}$ production in treated calli

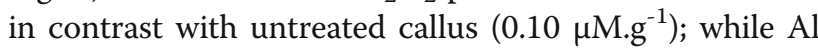
at $200 \mathrm{mg}^{-1} \mathrm{l}^{-1}$ led to a significant increase in $\mathrm{H}_{2} \mathrm{O}_{2}$ production which reached to $0.52 \mu \mathrm{M.g}^{-1}$. Peroxidase was noted to be increased significantly as a response to $\mathrm{Al}$ treatments, peroxidase activity was 8.8 unit. $^{-1} \cdot \mathrm{min}^{-1}$ in untreated calli, and the activity reached maximum value (12.66 unit. $\left.\mathrm{g}^{-1} \cdot \mathrm{min}^{-1}\right)$ in $\mathrm{Al}$ at concentration of 200 mg. ${ }^{-1}$. Interestingly, all $\mathrm{Al}$ treatments (50, 100 and 150 mg. $\mathrm{l}^{-1}$ ) led to a significant activity of peroxidase compared with control one.

\section{Protein analysis}

SDS-PAGE analysis of protein pattern from date palm callus treated with different concentrations of $\mathrm{Al}$

Table 2 Carbohydrates, protein, free amino acids, malondialdehyde, $\mathrm{H} 2 \mathrm{O} 2$ contents and peroxidase activity of date palm callus in response to Al stress

\begin{tabular}{lllllll}
\hline $\begin{array}{l}\text { Al concentration } \\
\left(\mathrm{mg} . \mathrm{l}^{-1}\right)\end{array}$ & $\begin{array}{l}\text { Total soluble carbohydrates } \\
\left(\mathrm{mg} \cdot \mathrm{g}^{-1}\right)\end{array}$ & $\begin{array}{l}\text { Total soluble protein } \\
\left(\mathrm{mg} \cdot \mathrm{g}^{-1}\right)\end{array}$ & $\begin{array}{l}\text { Free amino acids } \\
\left(\mathrm{mg} \cdot \mathrm{g}^{-1}\right)\end{array}$ & $\begin{array}{l}\text { MDA } \\
\left(\mathrm{nmole.} \mathrm{g}^{-1}\right)\end{array}$ & $\begin{array}{l}\mathrm{H}_{2} \mathrm{O}_{2} \\
\left(\mu \mathrm{M} \cdot \mathrm{g}^{-1}\right)\end{array}$ & $\begin{array}{l}\text { Peroxidase } \\
\left(\mathrm{unit} \cdot \mathrm{g}^{-1} \cdot \mathrm{min}^{-1}\right)\end{array}$ \\
\hline 0 & $5.87 \pm 0.36^{*}$ & $3.39 \pm 0.08$ & $1.66 \pm 0.07$ & $0.46 \pm 0.05$ & $0.10 \pm 0.01$ & $8.80 \pm 0.06$ \\
50 & $3.85 \pm 1.92$ & $1.82 \pm 0.04$ & $0.80 \pm 0.05$ & $0.56 \pm 0.04$ & $0.12 \pm 0.01$ & $9.65 \pm 0.12$ \\
100 & $1.97 \pm 0.08$ & $1.23 \pm 0.05$ & $0.60 \pm 0.03$ & $0.60 \pm 0.02$ & $0.25 \pm 0.04$ & $10.81 \pm 0.14$ \\
150 & $1.25 \pm 0.06$ & $0.78 \pm 0.07$ & $0.41 \pm 0.05$ & $0.71 \pm 0.04$ & $0.38 \pm 0.02$ & $11.89 \pm 0.04$ \\
200 & $0.54 \pm 0.06$ & $0.27 \pm 0.07$ & $0.16 \pm 0.02$ & $0.79 \pm 0.05$ & $0.52 \pm 0.03$ & $12.66 \pm 0.21$ \\
LSD & 1.60 & 0.11 & 0.10 & 0.07 & 0.30 & 0.24 \\
\hline
\end{tabular}

"Each value represent mean of triplicate $\pm S D$ 


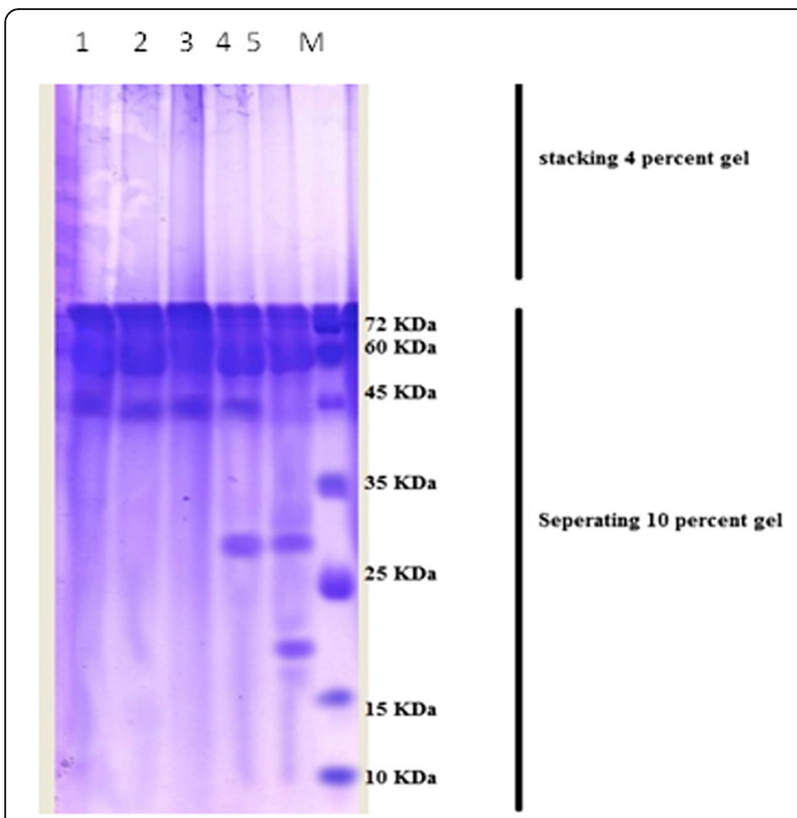

Fig. 4 SDS-PAGE profile of date palm callus treated with at different concentrations. M: Protein molecular marker; 1: control treatment; 2:

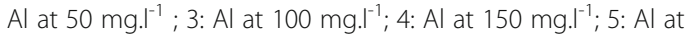
$200 \mathrm{mg}^{-1}$

compared to control treatment (Fig. 4, Table 3) revealed that, no difference of protein pattern for $\mathrm{Al}$ treatments at 50, $100 \mathrm{mg}^{-1} \mathrm{l}^{-1}$ compared to control treatment, which produced three fragments at sizes of 77,54 and $42 \mathrm{KDa}$ as molecular weight. A small difference in Al treatment at $150 \mathrm{mg} \cdot \mathrm{l}^{-1}$ was observed, in comparison with control treatment, newly appeared polypeptide with the size of $29 \mathrm{KDa}$ was seen. The major difference distinguished with increase $\mathrm{Al}$ to $200 \mathrm{mg} . \mathrm{l}^{-1}$, two new expressed polypeptides with the sizes of 29 and $29 \mathrm{KD}$ were observed a, interestingly, fragment with the size $42 \mathrm{KDa}$ was disappeared compared to control treatment.

The results of Table 4 represent the genetic similarities index (GSI) values according to presence and absence of fragments, the results showed the highest GSI value was observed in control treatment and $\mathrm{Al}$ treatments at 50 and $100 \mathrm{mg}^{-1}$ (100\%), while it was (75\%) between control and $\mathrm{Al}$ at $150 \mathrm{mg} \cdot \mathrm{l}^{-1}$, the lowest GSI value was reported in control treatment and $\mathrm{Al}$ treatment at $200 \mathrm{mg} \cdot \mathrm{l}^{-1}$ (50\%).

The dendrogram was created according to genetic distance index (Fig. 5) of protein profile, the cluster grouping showed that all treatments were separated into three clusters, the first included $\mathrm{Al}$ treatments at 50, 100 mg. $\mathrm{l}^{-1}$ and control treatment, while the second included only $\mathrm{Al}$ treatment at $150 \mathrm{mg} . \mathrm{l}^{-1}$, while $\mathrm{Al}$ at $200 \mathrm{mg} . \mathrm{l}^{-1}$ was separated in the third cluster.

\section{Discussion}

Results showed that $\mathrm{Al}$ at all examined concentrations significantly affected date palm callus growth. Our findings were based on fresh and dry weight. $\mathrm{Al}$ supple-

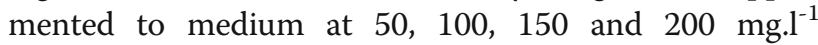
concentrations reduced the fresh weight of callus by approximately $52.11 \%, 63.65 \%, 77.25 \%$ and $92.06 \%$, respectively, and that of dry weight by approximately $47.84 \%, 58.19 \%, 67.67 \%$ and $83.18 \%$, respectively, compared with that of the control treatment. The results in Fig. 3 show that the number of embryos produced on the date palm callus significantly decreased with increasing $\mathrm{Al}$ concentration. Furthermore, $\mathrm{Al}$ at $200 \mathrm{mg} \cdot \mathrm{l}^{-1}$ prevented date palm callus to produce any embryo.

The phytotoxicity of $\mathrm{Al}$ at the examined concentrations could be attributed to the inhibition of cell elongation ad division at high concentration (200 mg. $\mathrm{l}^{-1}$ ) but only cell elongation at low concentration [27]. Low Al concentrations induce endogenous nitric acid production and may inhibit cell elongation [16]. In addition, the presence of $\mathrm{Al}$ ion in medium limits the transport of many nutrients and blocks their contribution in the metabolic system [33]. High $\mathrm{Al}$ concentrations decrease the uptake of nutrients, such as $\mathrm{Mg}, \mathrm{Ca}, \mathrm{P}, \mathrm{K}, \mathrm{Zn}$ and $\mathrm{Fe}$ [13]. The inhibition effect of $\mathrm{Al}$ on elongation and cell death might involve two phases; the early phase is distinguished by low sugar uptake and inhibition elongation, and the later phase is involved in ROS generation, eventually leading to cell death [4]. ROS production, respiration inhibition and ATP depletion are important events of Al toxicity in plant cells [49].

Our results in Table 2 indicate a significant decrease in the content of total soluble carbohydrates, total

Table 3 Protein profile (presence and absence) in callus of date palm treated with Al (mg. I $^{-1}$ ) obtained by SDS-PAGE technique

\begin{tabular}{llllll}
\hline Lane number of band & Molecular weight of band (KDa) & 0 & 50 & 100 & 150 \\
\hline 1 & 77 & 1 & 1 & 1 & 1 \\
2 & 54 & 1 & 1 & 1 & 1 \\
3 & 42 & 1 & 1 & 1 & 1 \\
4 & 29 & 0 & 0 & 0 & 1 \\
5 & 19 & 0 & 0 & 0 & 0 \\
Total number of bands & & 3 & 3 & 3 & 4 \\
\hline
\end{tabular}


Table 4 Similarity indices according to Nei and Li's coefficients of treated date palm callus with several concentrations of Al obtained by SDS-PAGE electrophoresis

\begin{tabular}{llllll}
\hline Al Concentration mg. ${ }^{-1}$ & 0 & 50 & 100 & 150 & 200 \\
\hline 0 & 1 & 1 & 1 & 0.75 & 0.5 \\
50 & 1 & 1 & 1 & 0.75 & 0.5 \\
100 & 1 & 1 & 1 & 0.75 & 0.5 \\
150 & 0.75 & 0.75 & 0.75 & 1 & 0.5 \\
200 & 0.50 & 0.50 & 0.50 & 0.75 & 1 \\
\hline
\end{tabular}

soluble protein and free amino acids of date palm callus, and this trend is inversely proportional to the increase in Al concentration. ATP depletion reduced the energy supply needed for protein synthesis, which can explain the reduction in protein level and free amino acids. $\mathrm{Al}$ reduces the total soluble proteins in sorghum plants [10]. In this study, the date palm callus showed significantly increased MDA and $\mathrm{H}_{2} \mathrm{O}_{2}$ level and increased peroxidase activity. Lipid peroxidation is of the first symptoms of Al toxicity in plant cells [34, 49, 51]. The MDA content in date palm callus treated with $\mathrm{Al}$ at 200 mg. ${ }^{-1}$ was increased by up to 1.71 -fold compared with that in the control callus. Lipid peroxidation was also induced under $\mathrm{Al}$ stress [14, 19, 27, 35]. The increase in lipid peroxidation may be attributed to the binding of $\mathrm{Al}$ to biomembrane and leads to rigidity, which in turns causes the generation of radical chain reactions by $\mathrm{Fe}$ ions [21, 48]. $\mathrm{H}_{2} \mathrm{O}_{2}$ accumulation in date palm callus was increased up to 5.2-fold when exposed to $\mathrm{Al}$ compared with that in the control treatment. Al triggers the production of ROS, including $\mathrm{O}_{2}^{-}$[9]. The enzyme super oxide dismutase (SOD) catalyses the dismutation of $\mathrm{O}_{2}{ }^{-}$ into $\mathrm{H}_{2} \mathrm{O}_{2}$ as a fairly stable form of ROS and $\mathrm{O}_{2}$ [6]. The increase in $\mathrm{H}_{2} \mathrm{O}_{2}$ level in date palm callus under $\mathrm{Al}$ treatments may be correlated with the increased SOD activity.
The results showed substantially increased peroxidase (POD) enzyme activity for the plants exposed to all experimented $\mathrm{Al}$ concentrations. The highest level was observed in date palm callus grown at medium containing $200 \mathrm{mg} . \mathrm{l}^{-1} \mathrm{Al}$, showing 1.43-fold more enzyme activity compared with the control treatment. Different genes encoding peroxidase enzymes were expressed under $\mathrm{Al}$ exposure in Arabidopsis thaliana after $1 \mathrm{~h}$ [36]. POD acts as a scavenger of toxic lipids and hydroperoxides generated from lipid peroxidation under $\mathrm{Al}$ stress [43]. Peroxidase also contributes to $\mathrm{H}_{2} \mathrm{O}_{2}$ detoxification by converting it into oxygen and water molecules [30]. In this study, the protein profile results showed that date

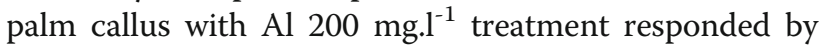
synthesising two new peptides with molecular weights of 19 and $29 \mathrm{KDa}$. A $42 \mathrm{KDa}$ peptide disappeared, and a 29 KDa peptide appeared after the treatment with 150 mg. $l^{-1} \mathrm{Al}$. These new peptides may have relevant roles in Al binding and may be low-molecular-weight proteins produced in plants as a response to abiotic stress [12]. The change in plant protein expression as detected by SDS PAGE after Al and other heavy metal stress was observed $[2,12,44,46]$.

\section{Conclusion}

Our results highlighted for the first time the phytotoxic and genotoxic effect of $\mathrm{Al}$ at different concentrations (50, 100, 150 and $200 \mathrm{mg}^{-\mathrm{l}^{-1}}$ ) on the in vitro cultures of date palm Hillawii cultivar. Generally, the growth and biochemical characteristics were reduced significantly after $\mathrm{Al}$ exposure. $\mathrm{Al}$ at 150 and $200 \mathrm{mg}^{-\mathrm{l}^{-1}}$ decreased the fresh and dry weight and number of embryos in date palm callus compared with those in untreated ones. Total carbohydrates, total soluble proteins and free amino acids were also reduced significantly in the cultured tissues after $\mathrm{Al}$ treatments. MDA, $\mathrm{H}_{2} \mathrm{O}_{2}$ and peroxidase were increased in response to ROS generation in

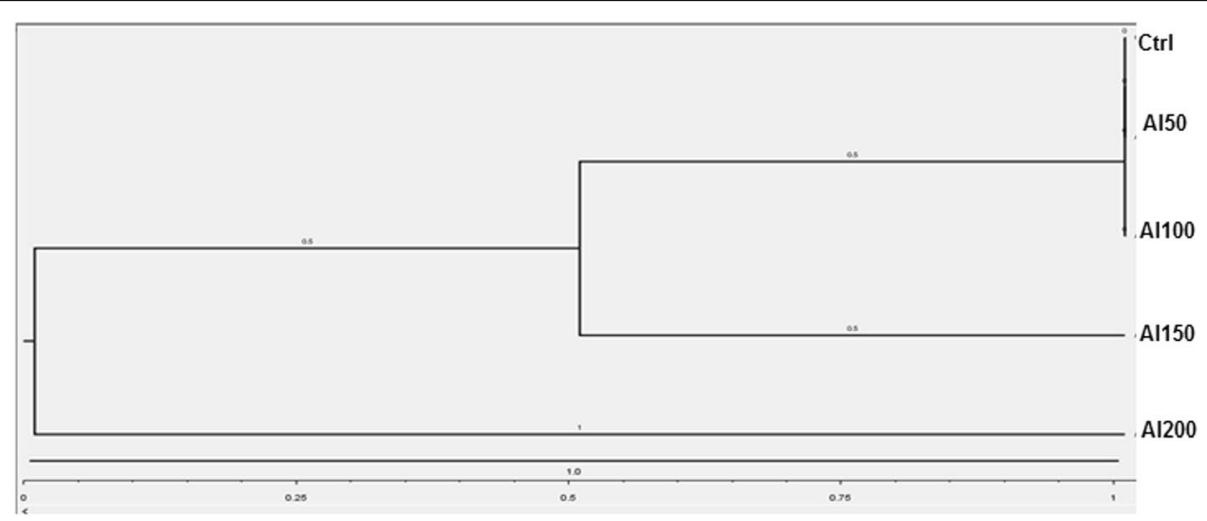

Fig. 5 Dendrograms generated by UPGMA cluster method based on Protein SDS-PAGE electrophoresis Ctrl: Control, Al50: Al at 50 mg/ $\mathrm{L}^{-1}$, Aa100: Al at $\mathrm{mg} / \mathrm{L}^{-1}$, Al150: Al at $150 \mathrm{mg} / \mathrm{L}^{-1}$, Al200: Al at $200 \mathrm{mg} / \mathrm{L}^{-11}$ 
exposed calli. Genetic analysis by SDS-PAGE technique revealed that $\mathrm{Al}$ at 150 and $200 \mathrm{mg} \cdot \mathrm{l}^{-1}$ induced the expression of the polypeptides of 29 and $19 \mathrm{KDa}$ compared with that in the untreated ones. Our findings shed light on the importance of in vitro technique for further understanding of $\mathrm{Al}$ toxicity in date palm. Future research may be conducted to examine the effects of other $\mathrm{Al}$ concentrations on date palm cultured tissues and to evaluate genotoxicity. Furthermore, a tissue culture approach can be used to produce plants tolerant to $\mathrm{Al}$ toxicity.

\section{Abbreviations \\ FAA: free amino acid; GD: genetic distance; GS: genetic similarity; $\mathrm{H}_{2} \mathrm{O}_{2}$ : Hydrogen Peroxide; KDa: kilo dalton; MDA: malondialdhyde; POD: peroxidase; ROS: reactive oxygen species; RPM: revolution per minute; RT: room temperature; SDS-PAGE: sodium dodecyl sulfate- polyacrylamide gel electrophoresis; UPGMA: unweighted pair group mean average}

\section{Acknowledgements}

All authors would like to acknowledge the Date Palm Research Centre; University of Basra for providing all necessary materials and support the current study.

\section{Authors' contributions}

KMA carried out the biochemical analysis. AMS carried out the tissue cultures experiments. YNK participated in the biochemical experiments. AAS participated in the design of the study and performed the statistical analysis. MHA carried out genetic analysis and conceived of the study, and participated in its design and coordination and helped to draft the manuscript. All authors read and approved the final manuscript.

\section{Funding}

Not applicable.

\section{Availability of data and materials}

Not applicable.

\section{Ethics approval and consent to participate}

Not applicable.

\section{Consent for publication}

Not applicable.

\section{Competing interests}

The authors declare that they have no competing interests.

\section{Author details}

${ }^{1}$ Date Palm Research Centre, University of Basra, Basra, Iraq. ${ }^{2}$ Plant Protection Department, College of Agriculture, University of Basra, Basra 61001, Iraq.

Received: 9 July 2019 Accepted: 10 September 2019

Published online: 21 October 2019

\section{References}

1. Abass MH (2017) Molecular Identification of Fungal Contamination in Date Palm Tissue Cultures. In: Al-Khayri J, Jain S, Johnson D (eds) Date Palm Biotechnology Protocols Volume II. Methods in Molecular Biology, vol 1638. Humana Press, New York

2. Abass MH, Namea JD, Al-Jabary KMA (2018) Cadmium and lead-induced genotoxicity in date palm (Phoenix dactylifera L.) cv. Barhee. Basrah J Date Palm Res 17(1-2):16-34

3. Abass MH, Neama JD, Al-Jabary KMA (2016) Biochemical responses to cadmium and lead stresses in date palm (Phoenix dactylifera L.) plants. Adv Agric Botanics 8(3):92-110 Available at http://www.aab.bioflux.com.ro/ docs/2016.92-110.pdf

4. Abdel-Basset R, Ozuka S, Demiral T, Furuichi T, Sawatani I, Baskin TI, Yamamoto Y (2010) Aluminium reduces sugar uptake in tobacco cell cultures: a potential cause of inhibited elongation but not of toxicity. J Exp Bot 61(6):1597-1610

5. Al-Khayri JM (2010) Somatic Embryogenesis of Date Palm (Phoenix dactylifera L.) Improved by Coconut Water. Biotechnology 9:477-484

6. Berwal MK, Sugatha P, Niral V, Hebbar KB (2016) Variability in superoxide dismutase isoforms in tall and dwarf cultivars of coconut (Cocos nucifera L.) leaves. Indian J Agric Biochem 29(2):184-188

7. Bojarczuk K (2004) Effect of Aluminium on the Development of Poplar (Populus tremula L. $\times$ P. alba L.) in vitro and in vivo. Polish. J. Environ Stud 13(3):261-266 Available at http://www.pjoes.com/Effect-of-Aluminium-onthe-Development-of-Poplar-r-n-Populus-tremula-L-P-alba-L-in,87655,0,2.html

8. Bradford MM (1976) A rapid and sensitive method for the quantitation of microgram quantities of protein utilizing the principle of protein-dye binding. Anal Biochem 38:248-252

9. Chowra U, Yanase E, Koyama H, Panda SK (2016) Aluminium-induced excessive ROS causes cellular damage and metabolic shifts in black gram Vigna mungo (L.) Hepper. Protoplasma 254(1):293-302

10. Cruz FJR, Lobato AKKS, Costa RCL, Lope MJS, Neves HKB, Neto CFO, Silva MHL, Filho BGS, Lima AL Jr, Okumura RS (2011) Aluminum negative impact on nitrate reductase activity, nitrogen compounds and morphological parameters in sorghum plants. Aust J Crop Sci 5:641-645 Available at http:/ www.cropj.com/silva_5_6_2011_641_645.pdf

11. Darko E, Ambrusa H, Stefanovits-Banyai E, Fodor J, Bakos F, Barnabas B (2004) Aluminum toxicity, Al tolerance and oxidative stress in an Al sensitive wheat genotype and in Al-tolerant lines developed by in vitro microspore selection. Plant Sci 166:583-591

12. Duressa D, Soliman K, Chen D (2010) Identification of Aluminum Responsive Genes in Al-Tolerant Soybean Line PI 416937. Int J Plant Genomics 2010:1-13

13. Goransson A, Eldhuset TD (1995) Effects of aluminium ions on uptake of calcium, magnesium and nitrogen in Betula pendula seedlings growing at high and low nutrient supply rates. Water Air Soil Pollut 83(3-4):351-361

14. Guo T, Zhang G, Zhou M, Wu F, Chen J (2004) Effects of aluminum and cadmium toxicity on growth and antioxidant enzyme activities of two barley genotypes with different Al resistance. Plant Soil 258:241-248

15. Gupta N, Gaurav SS, Kumar A (2013) Molecular basis of aluminium toxicity in plants: a review. Am J Plant Sci 4(12):21-37

16. He H, Zhan J, He L, Gu M (2012) Nitric oxide signaling in aluminum stress in plants. Protoplasma 249(3):483-492

17. Heath RL, Packer L (1968) Photoperoxidation in isolated chloroplasts. I. Kinetics and stoichiometry of fatty acid peroxidation. Arch Biochem Biophys 125:189-198

18. Hing TW, Wei PW (2017) Effect of Aluminium on the Growth of Nodal Explants of Lobelia chinensis. J Eng Sci Res 1(2):43-46 Available at https:// www.jesrjournal.com/uploads/2/6/8/1/26810285/009-jesr-43-46

19. Hossain MA, Hossain AKMZ, Kihara T, Koyama H, Hara T (2005) AluminumInduced Lipid Peroxidation and Lignin Deposition Are Associated with an increase in $\mathrm{H} 2 \mathrm{O} 2$ generation in Wheat seedlings. Soil Sci Plant Nutr 51(2): 223-230

20. Ikegawa H, Yamamoto Y, Matsumoto H (2000) Responses to aluminium of suspension-cultured tobacco cells in a simple calcium solution. Soil Sci Plant Nutr 46:503-514 Available at https://www.tandfonline.com/doi/citedby/10.1 080/00380768.2000.10408803?scroll=top\&needAccess=true

21. Jones DL, Kochian LV (1997) Aluminum interaction with plasma membrane lipids and enzyme metal binding sites and its potential role in $\mathrm{Al}$ cytotoxicity. FEBS Lett 400:51-57

22. Kim YH, Yoo YZ (1996) Peroxidase production from carrot hairy root cell culture. Enzym Microb Technol 18:531-536

23. Kochian LV, Pineros MA, Hoekenga OA (2005) The physiology, genetics and molecular biology of plant aluminum resistance and toxicity. Plant Soil 274: 175-195

24. Laemmli UK (1970) Cleavage of structural proteins during the assembly of the head of bacteriophage T4. Nature. 227:680-685

25. Lee YP, Takahashani T (1966) An improved colorimetric determination of amino acids with the use of ninhydrine. Anal Biochem 14:71-77

26. Liu Q, Yang JL, He LS, Li YY, Zheng SJ (2008) Effect of aluminum on cell wall, plasma membrane, antioxidants and root elongation in triticale. Biol Plant 52:87-92

27. Ma Q, Rengel Z, Kuo J (2002) Aluminium toxicity in rye (Secale cereale): root growth and dynamics of cytoplasmic $\mathrm{Ca} 2+$ in intact root tips. Ann Bot 89(2):241-244 
28. Meredith CP (1978) Response of cultured Tomato cells to Aluminum. Plant Sci Lett 12:17-24

29. Meyer TS, Lambert BL (1965) Use of coomassie brilliant blue R250 for the electrophoresis of microgram quantities of parotid saliva proteins on acrylamide-gel strips. Biochem Biophys Acta 107:144-145

30. Minibayeva F, Kolesnikov O, Chasov A, Beckett RP, Luthje S, Vylegzhanina N, Buck F, Bottger M (2009) Wound-induced apoplastic peroxidase activities: their roles in the production and detoxification of reactive oxygen species. Plant Cell Environ 32:497-508

31. Murashige T, Skoog F (1962) A revised medium for rapid growth and bioassays with tobacco tissue culture. Physiol Plant 15:473-479

32. Nei M, Li W (1979) Mathematical model for studying genetic variation in terms of restriction endonucleases (molecular evolution/ mitochondrial DNA/nucleotide diversity). Proc Natl Acad Sci U S A 79(10):5269-5273

33. Oleksyn J, Karolewski P, Giertych MJ, Werner A, Tjoelker MG, Reich PB (1996) Altered root growth and plant chemistry ofPinus sylvestris seedlings subjected to aluminum in nutrient solution. Trees. 10(3):135-144

34. Panda SK, Chaudhury I, Khan MH (2003) Heavy Metals Induce Lipid Peroxidation and Affect Antioxidants in Wheat Leaves. Biol Plant 46(2):289294 Available at https://link.springer.com/article/10.1023/A:1022871131698

35. Poot-Poot W, Rodas-Junco BA, Munoz-Sanchez JA, Hernández-Sotomayor SMT (2016) Protoplasts: a friendly tool to study aluminum toxicity and coffee cell viability. SpringerPlus 5:1542 https://doi.org/10.1186/s40064-0163140-2

36. Richards KE, Schott EJ, Sharma YK, Davis KR, Gardner RC (1998) Aluminum induces oxidative stress genes in Arabidopsis thaliana. Plant Physiol 116: 409-418

37. Rout G, Samantaray S, Das P (2001) Aluminium toxicity in plants: a review. Agronomie. 21:3-21

38. Sade H, Meriga B, Surapu V, Gadi J, Sunita MSL, Suravajhala P, Kavi Kishor PB (2016) Toxicity and tolerance of aluminum in plants: tailoring plants to suit to acid soils. BioMetals. 29(2):187-210

39. Schmohl N, Horst WJ (2000) Cell wall pectin content modulates aluminium sensitivity of Zea mays (L.) cells grown in suspension culture. Plant Cell Environ 23:735-742

40. Sergiev I, Alexieva V, Karanov EV (1997) Effect of spermine, atrazine and combination between them on some endogenous protective systems and stress markers in plants. C R Acad Bulg Sci 51:121-124 Available at https:// www.scienceopen.com/document?vid=9a910396-bee5-40d8-b1cd-3784 9faee 836

41. Silva S (2012) Aluminium Toxicity Targets in Plants. J Bot 2012:1-8 https:// doi.org/10.1155/2012/219462

42. Sneath PHA, Sokal RR (1973) Numerical Taxonomy: The Principles and Practice of Numerical Classification, W.H. Freman, San Francisco

43. Tamas L, Huttova J, Mistrik I (2003) Inhibition of Al-induced root elongation and enhancement of Al-induced peroxidase activity in Al-sensitive and Alresistant barley cultivars are positively correlated. Plant Soil 250(2):193-200

44. Tammam AA, Khalil SM, Hafez EE, Elangar AM (2018) Impacts of Aluminum on Growth and Biochemical Process of Wheat Plants Under Boron Treatments. Curr Agric Res J 6(3):300-309

45. Toan NB, Ve NB, Debergh PC (2004) Tissue culture approaches for the selection of aluminium-tolerant Citrus species in the Mekong Delta of Vietnam. J Hortic Sci Biotechnol 79(6):911-916

46. Udengwu OS, Egedigwe UO (2013) Aluminium toxicity induced stress alters protein profile of Amaranthus hybridus leaves. Plant Prod Res J 17:20-25 Available at https://www.researchgate.net/publication/315815183

47. Watanabe S, Kojima K, Ide Y, Sasakii S (2000) Effect of saline and osmotic stress on proline and sugar accumulation in Populus euphratica in vitro. Plant Cell Tissue Organ Cult 63:199-206

48. Yamamoto Y, Kobayashi Y, Devi SR, Rikiishi S, Matsumoto H (2003) Oxidative stress triggered by aluminum in plant roots. Plant Soil 255:239-243

49. Yamamoto $Y$, Kobayashi Y, Devi SR, Rikiishi S, Matsumoto H (2002) Aluminum toxicity is associated with mitochondrial dysfunctionand the production of reactive oxygen species in plant cells. Plant Physiol 128:63-72

50. Yamamoto Y, Rikiishi S, Chang YC, Ono K, Kasai M, Matsumoto H (1994) Quantitative estimation of aluminium toxicity in cultured tobacco cells: correlation between aluminium uptake and growth inhibition. Plant Cell Physiol 35:575-583

51. Yamamoto $Y$, Kobayashi $Y$, Matsumoto $H$ (2001) Lipid peroxidation is an early symptom triggered by aluminum, but not the primary cause of elongation inhibition in pea roots. Plant Physiol 125:199-208
52. Zaid A, De Wet PF (2002) Botanical and systematic description of the date palm. In: Zaid A, Arias-Jimenez EJ (eds) Date Palm Cultivation. FAO Plant Production and Protection Rev.1, Rome, p 156

53. Zayed ZE, El Dawayati MM, El Sharabasy SF (2019) Total steroids production from date palm callus under heavy metals stress. Biosci Res 16(2):1448-1457

\section{Publisher's Note}

Springer Nature remains neutral with regard to jurisdictional claims in published maps and institutional affiliations.

\section{Submit your manuscript to a SpringerOpen ${ }^{\circ}$ journal and benefit from:}

- Convenient online submission

Rigorous peer review

- Open access: articles freely available online

High visibility within the field

- Retaining the copyright to your article

Submit your next manuscript at $\boldsymbol{\nabla}$ springeropen.com 